Progress. Agric. 18(2) : 99-107, 2007

ISSN 1017-8139

\title{
STRUCTURAL DEVELOPMENT AND ESTABLISHMENT OF RAMPT MODELS IN ROADSIDE, FARMLAND AND OTHER SLOPELAND AGROFORESTRY
}

\author{
M. A. Hossain \\ Department of Agroforestry, Bangladesh Agricultural University \\ Mymensingh-2202, Bangladesh
}

\begin{abstract}
The three different models of Roadside Agroforest Multistoried Production Technologies (RAMPT) have been established at Bangladesh Agricultural University Campus, Mymensingh, Bangladesh. These are RAMPT-1 : Single Step Single Slope RAMPT [(SS) ${ }^{2}$ RAMPT], RAMPT-2 : Double Steps Double Slopes RAMPT [(DS)2 RAMPT], and RAMPT-3 : Triple Steps Triple Slopes RAMPT [(TS $)^{2}$ RAMPT]. The results of on-going experiments both on MPTS and herbaceous species including crops and medicinal plants under the above models have been observed to be effective and encouraging with a $100 \%$ success in tree plantation. Neem, Mehogani and Bakphul based multistoried production systems have been established with understoried shrubby and herbaceous species like Jatropha, lemon, Eryngium, sunflower, turmeric, stem amaranth, chilli, lady's finger (okra), sweet gourd, etc. The structural development and establishment of these models have been described.
\end{abstract}

Key Words : Farmland, Live fence, Multistoried, RAMPT model, Roadside agroforestry, Slopeland

\section{INTRODUCTION}

There remain huge fallowlands and wastelands along the sides of roads, highways, railways, embankments, homesteads, farm houses and farm boundaries, pondsides, lake and riversides, etc. These lands are needed to be brought under production systems (Hossain, 2006). Again, crop land 'ails' (bunds) as well as farm and homestead boundaries have to be used under specialized plantation systems to reduce friction and / or negative effects on others' land (Hossain, 1994, 1996). Bangladesh has about $4500 \mathrm{~km}$ of roads and highways, $16000 \mathrm{~km}$ of district council roads, $105000 \mathrm{~km}$ of thana and union parishad roads, $2900 \mathrm{~km}$ of railroads, $56000 \mathrm{~km}$ of river and coastal embankments, and about 2 million big and small ponds with prominent high banks. Specialized agroforests can be established there (Amin et al., 1996). With a view to bringing these fallow lands under planned development and cultivation along with soil conservation, landscape development and environmental benefits, the roadside agroforestry models have been outlined and established at Bangladesh Agricultural University Campus, Mymensingh (Hossain, 2006). The steps in structural development and establishment of these models are illustrated and described in this article. 


\section{MATERIALS AND METHODS}

The study was conducted and established along farm roadsides (starting from BINA farm side) of Bangladesh Agricultural University, Mymensingh, during the period from 2005 to 2007 . The area is located at $24^{\circ} 75^{\prime} \mathrm{N}$ latitude and $90^{\circ} 50^{\prime} \mathrm{E}$ longitude at a height of $18 \mathrm{~m}$ above the sea level (UNDP and FAO, 1988). The area is under tropical monsoon climate where rainfall is heavy, humidity and temperature are also high during April to September and low rainfall associated with low temperature during October to March. The winter season is dry and cool, and receives only $2 \%$ of the total rainfall mostly as occasional drizzles between November to February.

The plant materials used in this study were : 1. Neem (Azadirachta indica, A. Juss., Meliaceae), 2. Bara Mehogani (Swietenia macrophylla King., Meliaceae), 3. Bakphul (Sesbania grandiflora (L.) Poir., Leguminosae), 4. Jatropha (Jatropha curcas L., Euphorbiaceae), 5. Lemon (Citrus spp. L., Rutaceae), 6. Acalypha (Acalypha sp. L., Euphorbiaceae), 7. Eryngium (Eryngium foetideum L., Umbelliferae), 8. Sunflower (Helianthus annuus L., Compositae), 9. Turmeric (Curcuma longa L., Zingiberaceae), 10. Stem amaranth (Amaranthus oleraceus L., Amaranthaceae), 11. Chilli (Capsicum annuum L. and C. frutescens L., Solanaceae), 12. Ladies finger/okra (Abelmoschus esculentus (L.) Moen., Malvaceae), 13. Country bean (Dolichos lablab L., Leguminosae), 14. Bitter gourd (Momordica charantia L., Cucurbitaceae), 15. Tomato (Lycopersicon esculentum Mill., Solanaceae) and 16. Sweetgourd (Cucurbita maxima Duch., Cucurbitaceae).

The Neem and Mehogani are high quality and valuable timber yielding plants having medicinal and insecticidal properties. These plants are propagated mainly through seeds (Khan and Alam, 1996). Bakphul is a very fast growing tree (Khan and Alam, 1996) producing forage for animals, flowers as vegetables, root and shoot biomass (with continuous litter falls from standing trees) that improve soil quality both physically and chemically through the addition of atmospheric $\mathrm{N}_{2}$ and finally producing fuel woods. Jatropha is a biodiesel yielding shrubby to small tree like plant which can be grown in low to high rainfall areas (Openshaw, 2000) for long periods. The lemon is a bushy shrub and is well known for its fruit (citron) production. It has also medicinal values. In this study, the lemon plant has been used for both live fencing and protection purposes as well as for fruit production. Acalypha is a shrubby species and has been used as hedgerow along the innermost line (near foot path/side way) towards the main road, although it has good medicinal value. The rest of the species were mostly grown as understoried spices and vegetable crops as well as for soil conservation and erosion control.

A novel and specific design has been followed to maintain compatible environment and to reduce negative effects on growing crops of adjacent fields.

The design/principle of plantation followed in this study is that the first (inner) row of $\mathrm{big} /$ medium sized, strong and deep rooted trees like Mehogani, Neem etc. are planted near the side way/footpath, the small trees like Bakphul as outer line and alternate to that of big/medium tree, and then further smaller trees or shrubs are planted towards 
crop fields, so that the subsequent plants are grown, more or less, under the shades of first rows of trees having less or no adverse effect on crop fields.

The overall structural arrangements/designs (After Hossain, 2006) followed in this study are shown in Figs. 1-3.

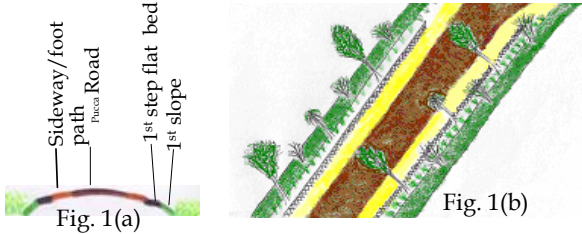

Fig. 1. Double sides of RAMPT-1
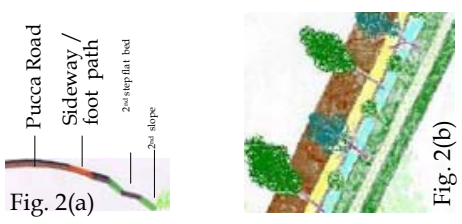

Fig. 2. Single side of RAMPT-2

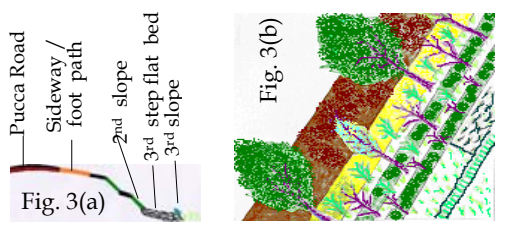

Fig. 3. Single side of RAMPT-3

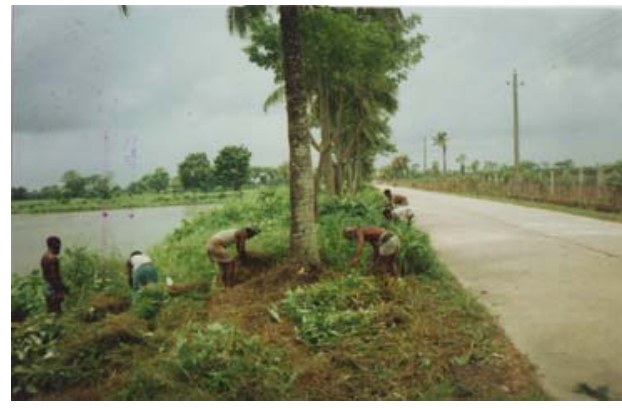

Fig. 4. Showing previous natural condition of roadsides and bush clearing activities

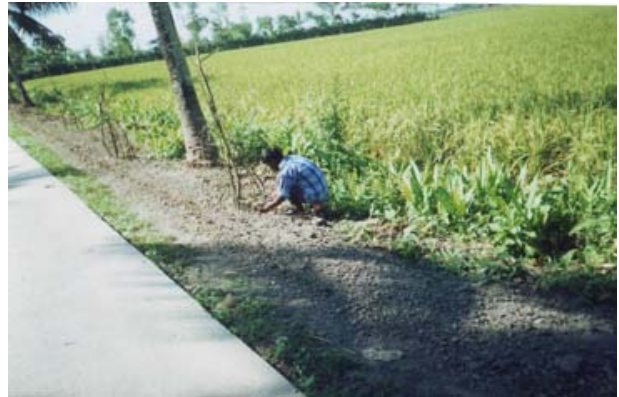

Fig. 5. Showing initial plantation of Neem saplings under thorn protection system

The roadsides under study, naturally covered with bushes, grasses and shrubby plants (Fig. 4), were first cleared, spaded and more or less uniformly levelled as slopeland. The uneven ridge-ditch conditions along pucca roadsides were also levelled with soil working and pressed firmly to obtain smooth and nice looking sideway/footpath. The first plantation of Neem (for RAMPT-1\&2) and Mehogani (for RAMPT-3) saplings of approximately 1 year old was carried out in early September of 2005 in a single row on the $1^{\text {st }}$ flat bed, leaving approximately $0.5 \mathrm{~m}$ wide area for beautifying cum protective hedgerow of Acalypha and/or lemon in between the sideway/footpath and the first row 
of tree saplings. Simultaneously modification and improvement of the rest of the outer areas of roadsides were also done as shown in Figs. 1-3.

Thorny branches of Parkinsonia aculeata L. and Ziziphus mauritiana Lamk. were used for initial protection of these planted saplings (Fig. 5). Subsequently lemon cuttings followed by Acalypha cuttings were planted to develop live fencing system on the innerside of tree saplings and outerside of sideway/footpath. In some other cases, Duranta hedgerow was established along lemon cuttings instead of Acalypha. Due to thorny nature, this Duranta and lemon fencing was placed on outer side of first row of tree saplings. The temporary nylon net fencing/bamboo cross-stick fencing was given in between side way/ footpath and developing live fences to have initial protection of cuttings and understoried crops. The first flat bed of about $0.5-1.5 \mathrm{~m}$ wide (depending upon land situation) for understoried crop cultivation (Fig. 6) along first row of tree plantation were prepared, sown/planted with crops followed by one or two (alternately arranged) rows of Eryngium on outer side of the $1^{\text {st }}$ flat bed to check soil erosion from the systems. For fruit (citron) production from the living fence, the branches from outer side of lemon hedgerows were allowed to extend outwards in between the growing crops/other plants on the $1^{\text {st }}$ flat bed.

Following the preparation of the $1^{\text {st }}$ flat bed, a shallow slope of about $0.5-1.5 \mathrm{~m}$ wide (depending upon the stiffness and land area) was prepared with necessary levelling/soil working followed by plantation of Bakphul (alternate to Neem with plant to plant distance of $5 \mathrm{~m}$ ) and Jatropha (in between the Bakphul saplings), either sparsely (Fig. 7, 11) or, continuously maintaining plant to plant distance of at least $1.0 \mathrm{~m}$.

Simultaneously an alternate arrangement of flat beds and slopes were made (Figs. 1-3) as and when necessary according to Hossain (2006). The roadside models were named depending upon the wideness of the roadsides and the number of flat beds/ slopes covered as shown in Figs. 1-3. Crops were grown following standard methods as described by Razzaque et al. (2000).

\section{RESULTS AND DISCUSSION}

The results on different stages of development and establishment of RAMPT models along with the plantation of trees and crops, and their subsequent growth and development are briefly described below.

\section{Plant growth and development}

The survival percentages in establishment of MPTS, their growth and development in terms of per cent success, shoot development, plant height, branch number and branch length are shown in Table 1 and Figs. 6-17.

The results presented in Table 1 clearly indicate that the RAMPT model protection systems showed $80-100 \%$ survival of saplings compared to only $00-18 \%$ under other protection systems along the roadsides. Again, gaurded condition to look after the 
growing saplings under managed and thorn protection systems showed $100 \%$ success in Neem, Mehogani and Bakphul saplings at 2 years after plantation under RAMPT models. This might be due to the fact that the cattle, children and people expecting for branches and leaves could not touch and damage the saplings under these protection systems and thus they were saved, while saplings planted out side the model area were destroyed.

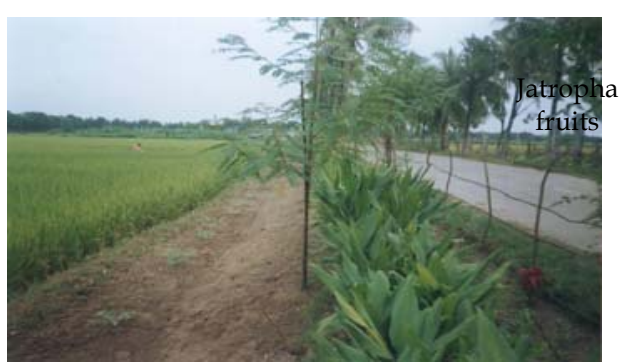

Fig. 6. Developing stages of RAMPT model with growing trees and crops (After Hossain, 2006)

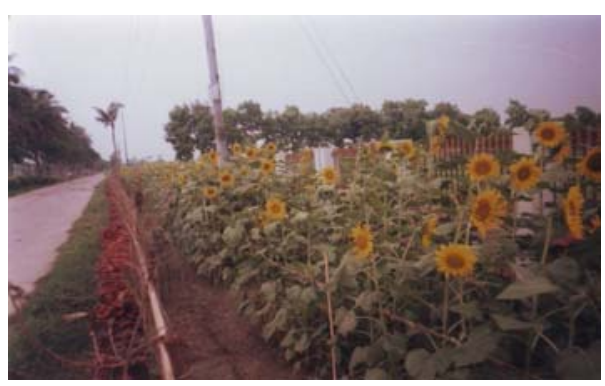

Fig. 8. Showing sunflower cultivation under the developing RAMPT model

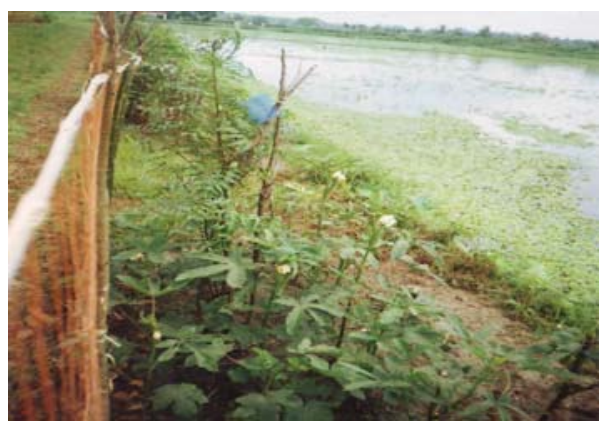

Fig. 10. RAMPT model with Neem and growing vegetable (lady's finger, stem amaranth)

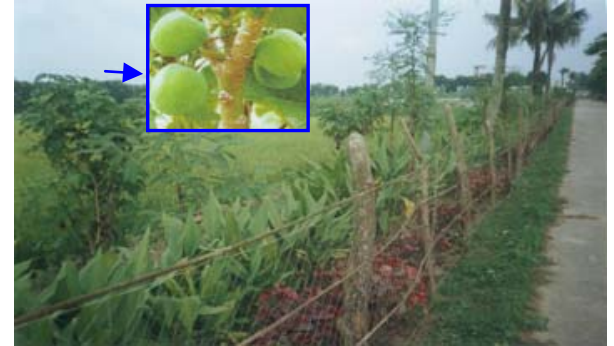

Fig. 7. Jatropha with other plantation along roadsides under RAMPT model

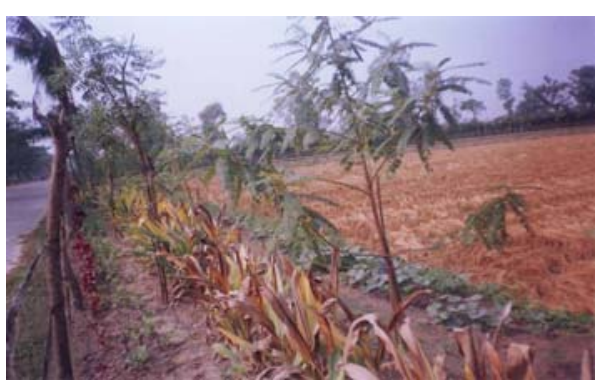

Fig. 9. RAMPT model with Neem and Bakphul trees having understoried sweet gourd and turmeric

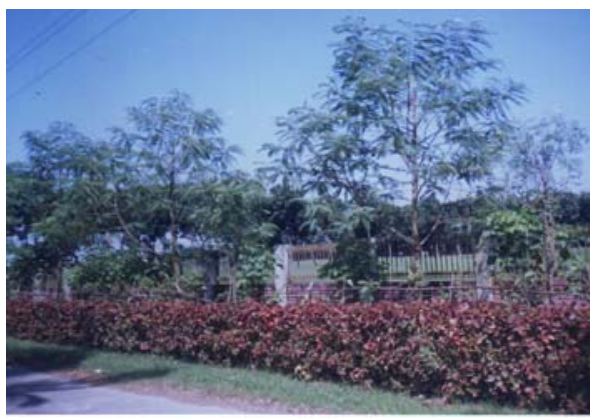

Fig. 11. Showing Neem, Bakphul and Jatropha grown under RAMPT model with developing lemon hedge and understoried crops remaining behind the Acalypha hedge 


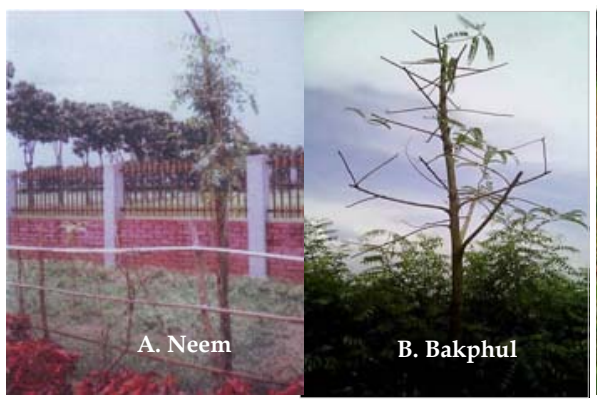
Fig. 12. Severe pruning of Neem and Bakphul
trees followed (Hossain, 1994) in order to maintain spacing, light passing and air flow systems in RAMPT models
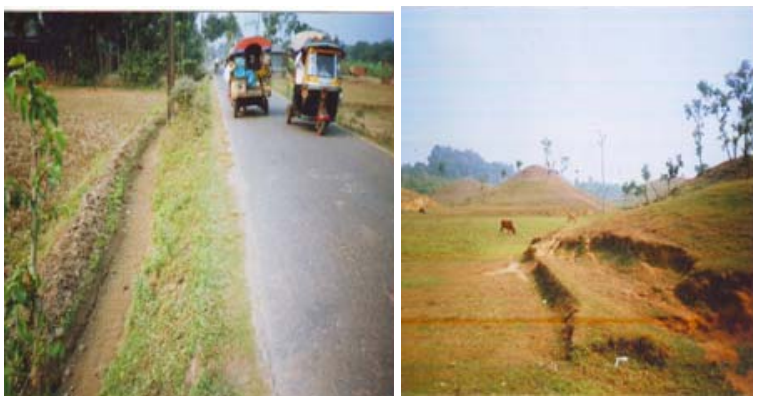

ig. 14. Denuded hill slopes damaged by irrigation canal. RAMPT models may be followed to save the roadsides (in Sylhet, Bangladesh) may be brought under RAMPT plantation

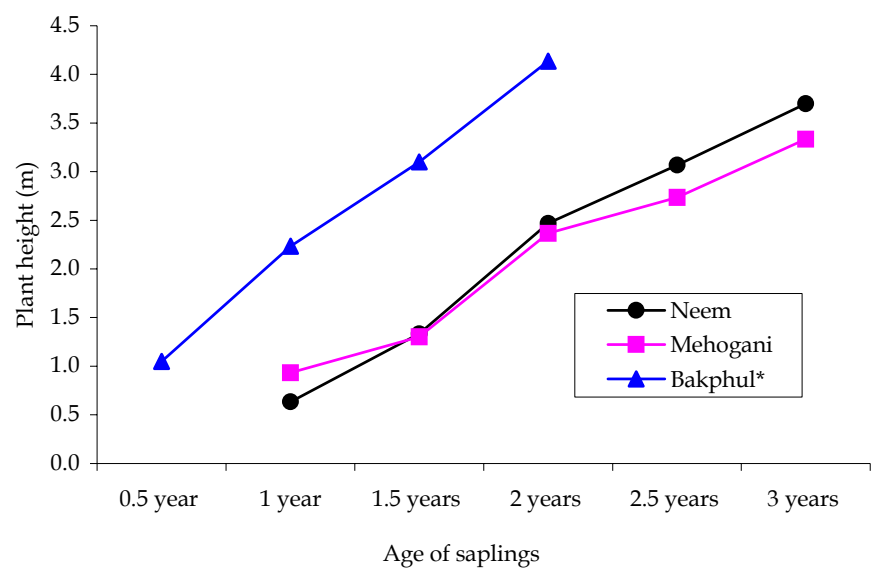

Fig. 15. Increase in plant height at different stages of growth of Neem, Mehogani and Bakphul * Bakphul was sown one year after Neem and Mehogani

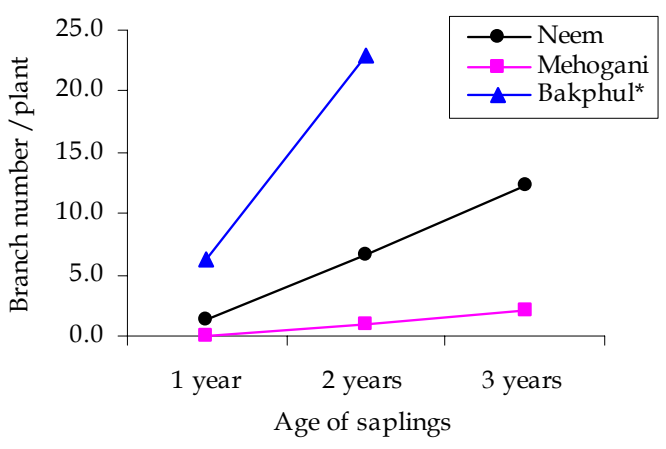

Fig. 16. Increase in number of branches at different stages of growth of Neem, Mehogani and Bakphul

* Bakphul was sown one year after Neem and Mehogani

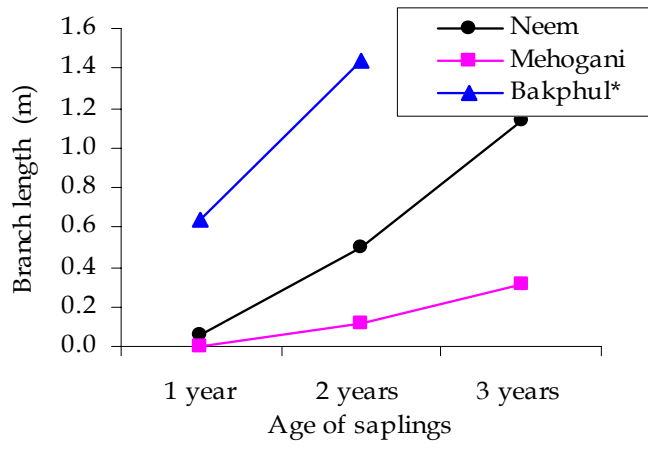

Fig. 17. Increase in length of branches at different stages of growth of Neem, Mehogani and Bakphul

* Bakphul was sown one year after Neem and Mehogani 
Table 1. Survival percentages of Neem, Mehogani and Bakphul two years after plantation along farm boundaries and roadsides of BAU under guarded and different fencing conditions

\begin{tabular}{|c|c|c|c|c|c|}
\hline Species & Planting sites & Fencing systems & Management conditions & $\begin{array}{l}\text { Number } \\
\text { of saplings } \\
\text { planted }\end{array}$ & $\begin{array}{c}\text { Survival } \\
\text { per cent } \\
(\%)\end{array}$ \\
\hline \multirow{7}{*}{ 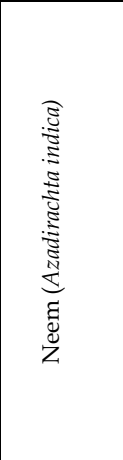 } & \multirow{2}{*}{$\begin{array}{l}\text { Agroforestry farm } \\
\text { boundaries }\end{array}$} & \multirow{2}{*}{$\begin{array}{l}\text { + Barbed wire } \\
+ \text { Live fence }\end{array}$} & $\begin{array}{l}\text { - Subsequent management } \\
\text { - Crop }\end{array}$ & $15^{*}$ & 87 \\
\hline & & & $\begin{array}{l}+ \text { Crops } \\
+ \text { Subsequent management }\end{array}$ & $85^{*}$ & 100 \\
\hline & \multirow{5}{*}{$\begin{array}{l}\text { Central farm } \\
\text { roadsides under } \\
\text { guarded } \\
\text { conditions }\end{array}$} & \multirow{2}{*}{$\begin{array}{l}\text { + Thorn protection } \\
+ \text { Support }\end{array}$} & -Subsequent management & $25^{*}$ & 80 \\
\hline & & & $\begin{array}{l}+ \text { Crops } \\
+ \text { Subsequent management }\end{array}$ & $20^{*}$ & 100 \\
\hline & & \multirow{2}{*}{$\begin{array}{l}\text { + Support } \\
\text { + Thorn protection } \\
\text { + Subsequent net fencing }\end{array}$} & - Subsequent management & $9^{*}$ & 100 \\
\hline & & & $\begin{array}{l}\text { + Crops } \\
+ \text { Subsequent management }\end{array}$ & $92^{*}$ & 100 \\
\hline & & $\begin{array}{l}\text { + Support } \\
\text { + Bamboo cage/gabion }\end{array}$ & $\begin{array}{l}\text { - Crop } \\
\text { - Subsequent management }\end{array}$ & $125^{* *}$ & 00 \\
\hline \multirow{3}{*}{ 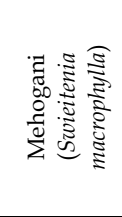 } & \multirow{3}{*}{$\begin{array}{l}\text { Central farm road } \\
\text { sides under guarded } \\
\text { conditions }\end{array}$} & \multirow{2}{*}{$\begin{array}{l}\text { + Support } \\
+ \text { Thorn protection }\end{array}$} & \begin{tabular}{|l} 
- Crop \\
- Subsequent management
\end{tabular} & $27^{*}$ & 93 \\
\hline & & & $\begin{array}{l}+ \text { Crop } \\
+ \text { Subsequent management }\end{array}$ & $19^{*}$ & 100 \\
\hline & & $\begin{array}{l}\text { + Support } \\
\text { + Bamboo cage/gabion }\end{array}$ & $\begin{array}{l}\text { - Crop } \\
\text { - Subsequent management }\end{array}$ & $125^{* *}$ & 18 \\
\hline $\begin{array}{l}\text { Bakphul } \\
\text { (Sesbania } \\
\text { grandiflora }\end{array}$ & $\begin{array}{l}\text { Central farm road } \\
\text { sides under guarded } \\
\text { conditions }\end{array}$ & $\begin{array}{l}\text { + Support } \\
+ \text { Thorn protection } \\
+ \text { Subsequent net fencing }\end{array}$ & $\begin{array}{l}+ \text { Crop } \\
+ \text { Subsequent management }\end{array}$ & $100^{*}$ & 100 \\
\hline $\begin{array}{l}\text { Jatropha } \\
\text { (Jatropha } \\
\text { curcas) }\end{array}$ & $\begin{array}{l}\text { Central farm road } \\
\text { sides under guarded } \\
\text { conditions }\end{array}$ & $\begin{array}{l}\text { + Support } \\
+ \text { Thorn protection } \\
\text { + Subsequent net fencing }\end{array}$ & $\begin{array}{l}+ \text { Crop } \\
+ \text { Subsequent management }\end{array}$ & $\begin{array}{c}27^{*}+ \\
\text { more } \\
\text { subsequently }\end{array}$ & 100 \\
\hline
\end{tabular}

* Grown in roadsides under RAMPT models; ** Grown in roadsides outside the RAMPT models

The Figs. 6 to 11 and 15-17 clearly indicate that very good growth of the planted saplings as well as growing crops under RAMPT models was obtained. This was resulted probably because that the trapped nutrients and decomposed biomass along roadsides under the multistoried systems were sufficient and ideal for growth of trees, shrubs and crops under the systems. The RAMPT models have appeared as the effective multistoried production systems having well-organized plantation with diversified plant species, and are expected to be sustainable since Bakphul is adding a huge quantity of leaf biomass (litter) and $\mathrm{N}_{2}$ to the systems. In addition, the wind blown nutrients are being trapped by the multistoried plant canopies developed along roadsides/boundaries and added to the soil by rain water. Both the litter and trapped nutrients improve physical structure and fertility of the soil. Therefore, during the $1^{\text {st }}$ year and $2^{\text {nd }}$ year of development of the systems, no addition of manure or fertilizer was necessary. No remarkable disease or insect infestation was noticed in the system, probably due to insect repellent system developed by the growing Neem/Mehogani plants and it might have effect on healthy growth and appearance of other trees and crops in the systems (Figs. 6-11). Quick and 
plenty of shoot regeneration was observed on Bakphul and Neem trees following severe pruning and pollarding of the plants. Therefore, a huge quantity of shoot production (Neem leaves, forage from Bakphul and their branches as fuel woods) is possible from the systems and may be utilized for understoried growing crops and other plants as well as for other commercial purposes.

The biodiesel yielding plant, Jatropha curcas, showed very good growth with normal flowering and fruiting under the developing RAMPT models. The plant also showed extensive shoot development following severe pruning at any level. Therefore, the RAMPT models may be followed for commercial production of biodiesel from this plant without affecting or reducing agricultural and/or forest production. The deciduous nature of J. curcas also encourages production of vegetable crops and other understoried herbaceous species in the systems during mid October to mid March in Bangladesh conditions by shedding leaves and increasing light intensity on understoried plants as well as by supporting the growing vines.

The soil working systems under RAMPT models, the grass or crop covers on slopes, the planned, well-organized, well-managed and diversified vegetation, their root systems as well as their litter mulches protect the soil from rain and wind erosion. However, in order to maintain sustainability of the system, the planting arrangements should normally be alternate to each other maintaining well- spacing, light passing and air flow facilities in the systems. The understoried growing crops in a multistoried system should also maintain the same or similar systems along with the adjustment of crop cultivation according to Razzaque et al. (2000). Medium to severe pruning of MPTS (with removal of $30-60 \%$ length of branches as shown in Fig. 12) according to Hossain (1994) should also be followed to make the tree stout and straight growing against windy and stormy weather as well as to reduce negative effects on understoried crops. Subsequent studies on roadside soil having multistoried trees, shrubs and crops are also necessary to comment on the sustainability of the systems. The situations as shown in Figs. 13 and 14 emphasize the establishment of RAMPT models to save the roadsides and similar other slopelands.

\section{CONCLUSION}

The $100 \%$ success in establishment of MPTS, and the growth and appearance of all the plants grown in the multistoried systems under RAMPT models have appeared to be very healthy and effective in production. Therefore, the RAMPT model plantation systems may be practiced to increase production and economic return, solve unemployment problems, save roadsides, hillsides, riversides and other slopelands as well as to have better environmental conditions of the country.

\section{ACKNOWLEDGEMENT}

The author thankfully acknowledges the partly financial and other relevant supports received from the BAU and BAURES authorities, and the Ministry of Science and 
Information \& Communication Technology, Government of the People's Republic of Bangladesh for this research.

\section{REFERENCES}

Amin, S. M. R., Ahmed, F. U. and Fattah, I. M. 1996. Social forestry in Bangladesh : Concept and present status. In : Agroforestry in Bangladesh. M. A. Haque (ed.). VFFP, SDC, Dhaka and BAU, Mymensingh, pp. 30-37.

Hossain, M. A. 1994. Pruning, training and management in woody plants. In : Village and Farm Forestry in Bangladesh (in Bengali). M. A. Haque (ed.). Joint Publ. BAU-SDC, Dhaka, pp. 92-107.

Hossain, M. A. 1996. Propagation and management of multipurpose trees. In : Agroforestry in Bangladesh. M.A. Haque (ed.). VFFP, SDC, Dhaka and BAU, Mymensingh, pp. 46-54.

Hossain, M. A. 2006. Development of models for sustainable multistoried production systems in roadside and farmland agroforestry. Extd. Summ., BAU Res. Prog., 17 : 37-38.

Khan, M. S. and Alam, M. K. 1996. Homestead flora of Bangladesh, BARC, IDRC, SDC, Dhaka.

Openshaw, K. 2000. A review of Jatropha curcas: an oil plant of unfulfilled promise. Biomass and Bioenergy, 19(1) : 1-15.

Razzaque, M. A., Sattar, M. A., Amin, M. S., Quium, M. A. and Alam, M. S. 2000. Krishi Projukti Hatboi (Handbook on Agro-technology), 2nd edn. Bangladesh Agric. Res. Inst., Gazipur.

UNDP (United Nations Development Program) and FAO (Food and Agricultural Organization). 1988. Land Resource Appraisal of Bangladesh for Agricultural Development. Rep. 2. Agroecol. Reg. Bangladesh, pp. 212-221. 